\title{
A Review of Gender Stereotypes in Education
}

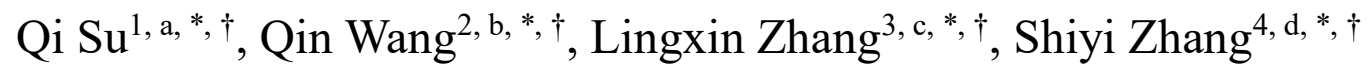

\author{
${ }^{1}$ Sichuan University, Sichuan Province, China \\ ${ }^{2}$ Huainan Normal University, Anhui Province, China \\ ${ }^{3}$ Zhejiang International Studies University, Zhejiang Province, China \\ ${ }^{4}$ Southlands Christian School, Los Angeles, California

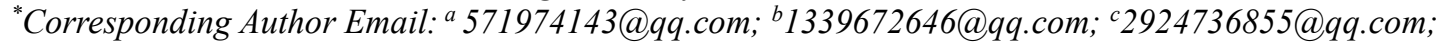 \\ ${ }^{d}$ shiyi.zhang@southlandscs.org \\ These authors contributed equally.
}

\begin{abstract}
Gender stereotype facilitates people categorize things and simplify everyday activities and cognitive processes, but the gender bias in society restricts the human development and fulfillment of the ideal. The terrain of gender stereotypes in education has witnessed much change in the twenty-first century. This paper provides a selective review of the literature on the empirical study and theoretical perspectives in educational performance and attainment from kindergarten to college over the recent decades. In addition, this paper remains a humble attempt at exploring the reasons behind gender inequalities in education at different levels: the development of gender identities, individual-level factors, and inequalities in attainment. Finally, the conclusion is discussed for stressing the negative influences that gender bias in the education field exerts on the youth, especially for females.
\end{abstract}

Keywords: Gender stereotype, gender bias, education.

\section{INTRODUCTION}

\subsection{Background of gender difference in education}

Gender stereotype is the overgeneralization of the characteristics and behaviour of individuals based on gender [1]. The realization of gender equality in school education is a global problem. Education reflects social value so that schools will faithfully copy the social value and impact on children. According to research, in some Western countries, girls are significantly better than boys in most areas through national qualifications and related assessments, especially in word recognition. In the field and career choice, it is subject to some restrictions and more pressure [2].

Local governments and schools are trying to improve the different problems caused by gender differences through policies and changing educational methods, but the effect is not obvious. For example, try to develop "specific" education based on gender characteristics by offering separate courses for male and female students [2]. There is very little evidence to show specific strategies for addressing gender inequality in vocational education by supporting students to learn non-traditional subjects or career choices. Of course, in addition to these innovations, any innovation requires the test of time because the attitude towards gender in education is not an easy thing to change.

\subsection{Gender difference From Kindergarten through High School}

Firstly, the textbook content reflects the stereotype of women. Mineshima suggested that in primary school textbooks, women's appearance scenes are mostly limited to the family [2]. There are two kinds of women in the text: one is the mother or wife who is hardworking and thrifty, the other is the mother or wife who is full of warmth, affection, and love for children. Therefore, there is only one kind of woman: mother or wife. Demira and Yavuz share the same view. Women are confined to the family, while most male characters in the textbooks are professional, knowledgeable, and management types [3]. The activity scenes of man are social. Therefore, there are great differences in the description of the contribution of men and women to society. The phenomenon of gender inequality and gender bias in the textbooks shows, on the one hand, our neglect, stereotype, and distortion of 
women in the ideological field. On the other hand, it also reveals the problems in our education process.

Secondly, gender consciousness influences students' choice of subjects. Buchmann and his colleagues indicated no intelligence gap brought by sex between boys and girls in the academic field [4]. After research, Buchmann et al. found that girls get better grades in the science field, if they take the same course as boys [4]. Freeman stated the same idea. From kindergarten to grade 12, girls have slightly higher average scores than boys. However, as young people enter high school, gender awareness affects their views on subjects. In particular, boys will think that mathematics and science are boys' specialties, while girls think that literature and art are more suitable. Therefore, this idea will affect students' future academic choices [5]. Therefore, education should be imparted impartially and neutrally. The concept of gender awareness is not determined by nature but cultivated through education.

\subsection{From High School to College}

The recent years have witnessed females' outperformance in high school education, college admissions, and college completion compared with male peers, shown by trend data in the United States [6]. In 1982, the proportion of women awarded academic degrees catch up with men's, and by 2005 females account for $58 \%$ of bachelor's degrees and $56 \%$ of all college students [6].

Both high school completion and college enrolment hold for gender inequalities in the transition to college. Completing high school in the United States is the first prerequisite for postsecondary education. Since 1990, the "status dropout rate" - the percentage of people aged 16 to 24 who are not enrolled in high school and have not obtained a high school diploma nor a Certificate of General Educational Development (GED), or other certificates of completion-for females has been lower than the rate for females [7]. In 2004, 11.6\% of males aged 16-24 dropped out of school, compared with $9 \%$ of females [8]. For students competing in high school, whether students entering directly after high school are related to whether they enroll in college [7]. Students who go to college directly after high school show a higher rate in the overall college enrollment, college persistence rate, and graduation indicated by Horn, Premo[9], Bozick, and Deluca's research [10]. In the past, males were more likely than females to enter college straight out of high school, but since 1996 the opposite has been true; In 2000, $66 \%$ of women did so, compared with $60 \%$ of men [11].

Historically, women have rarely been involved in the STEM field, mainly handled by males [12]. This situation corresponds with the social perception regarding gender. In patriarchal India, men are reputed as the providers of a family, and STEM field is highly-paid than art fields [13], males are thus encouraged to pick STEM field.

\subsection{Gender differences in the picture book}

Children's picture books play an important role in children's reading. Unlike textbooks, picture books mostly display pictures aimed at the masses, mostly children. The list of reading promotions includes "boys/girls must read" and "favorite reading". Gender stereotypes have a positive impact on the formation and development of children's gender identity.

This passage is about gender stereotypes and gender job assignments in picture books. In American picture books, the status and contribution of men and women in society have become a clear and basic creative consciousness. Many people's gender stereotypes of men and women remain active, and women are quiet; Male dominance, female subordination. Liu and Chen analysed gender bias in the promotion of morning reading in 2018 . In the 77 samples, there was no overlap between "boys must read" and "girls must read" picture books. According to such recommended lists, children who read often exhibit biased gender role characteristics prematurely and prematurely fix children's gender role characteristics [14]. Men have a higher proportion of occupations and a wider range of occupations [14]. Women's professional identity is relatively narrow, mostly in non-professional identities, such as housewives [14]. From cultural output and early childhood education, children's picture books need to meet international standards in form. They need to correctly influence the formation of children's gender role concepts [14]. Gender equality in picture books is important for building a child's character. We can intuitively feel that men and women can be the protagonists, leading their own stories no matter what kind of life scenes. For example, women can be police officers or firefighters, while men can be kindergarten teachers or nurses.

\section{CAUSES OF GENDER INEQUALITY}

\subsection{The development of gender identities}

Children's gender awareness of identities begins with the interaction of biological characteristics and development influence [15]. At birth, babies are divided into male or female according to their physiological characteristics. Gender identity usually develops in the following three stages: 1) Around the age of two, children begin to realize the physiological differences between boys and girls. 2) Before the third birthday: most children can easily label themselves as boys or girls. 3) At the age of four: most children have a stable understanding of their gender identity. During this time, children learn gender role behaviour, that is, to do "what boys do" or "what girls do" [15]. However, no matter what gender identity is in the future, cross gender preference, and cross gender 
games are normal components of gender development and exploration. The key is that over time, all children tend to have a clearer understanding of their gender.

Gender roles are shaped and constructed through social culture and are gradually internalized by children through the process of socialization [16]. According to different genders, social culture will set many cultural norms for its social members and become cultural societies [16]. Children at the age of three or even earlier know many of the activities and interests of gender roles [16]. For example, they know that boys should play with cars, knives, and guns, and girls should play dolls and cooking games. In primary school, children's knowledge of gender roles is more abundant, stable, and flexible [16] Studies have shown that children, due to the limitations of their cognitive development, usually regard rules as absolutely obedient requirements, so they can't tolerate the emergence of inappropriate gender behaviours. In contrast, older children can realize that rules are only a kind of social custom [16]. Due to the awakening of sexual consciousness, adolescents will have strong expectations of gender, so they will return to the stereotyped state of gender roles in their early days. In conclusion, the socialization of children's gender roles enables children to master different norms of different sex in a certain society to meet the expectations of a certain society.

\subsection{Individual-level Factors}

Allocation of family resources explains variations in an individual's postsecondary educational attainment [17, 18]. Children's gender, on the one hand, would exert different effects on the distribution of family resources, and thus leading to gender differences in post-secondary education. The "gender preference" hypothesis claims that if the parent(s) prefer(s) a child of a particular gender, the child of that gender may get more resources [19]. In patriarchal India, preference for sons is very evident, especially in poor families [20]. According to the patrilocal residence, females would leave their birth family and move to the husband's family. At the same time, males stayed home, which leads to fewer resources invested in females' education in poor families and thus greater advantages that males get in education in India [21]. It is found that, in China and Japan, significant gender differences in children's access to higher education as a result of the traditional concept of "boy preference" also occur [22, 23].

On the other hand, the family structure is also likely to affect the family's investment in their children's education. As shown in the resource dilution hypothesis, when the number of siblings in the family increases, each child can share tend to decrease [24-26]. Clark and Greenhalgh $[27,28]$ found that the first child born in the family possesses more resources than the child born later did because the desired financial return needs to be realized as soon as possible based on the human capital theory.

In short, kids' gender supported by the "gender preference" hypothesis and the family formation sustained by resource dilution hypothesis are significant factors to allocating family resources, thereby leading to gender differences in post-secondary education.

\subsection{Inequalities in attainment}

The process of role socialization accompanies the difference of attainment between men and women. First of all, the early socialization of the family has an important impact on the formation of the difference of attainment motivation between men and women. Rogers et al. have researched that parents have different attitudes towards the attainment trend of boys and girls. While encouraging boys to compete, forge ahead, achieve, and be independent, parents require girls to rely on, obey, cooperate [29]. They also hope that their daughter will have a good marriage. Therefore, this kind of different attitude will inevitably lead to men's higher attainment motivation than women's in the future life. Secondly, school education is also responsible for forming the differences in attainment motivation between men and women. In Popilskis's study, teachers in grade five and grade six were asked to rate their students [30]. The results showed that the girls' teachers liked most were not the girls who finished their studies best and worked hard, but the girls who were good at social and interpersonal relationships. But teachers like boys who are hardworking, but they don't pay much attention to boys' communication and behaviour. This may lead to girls' motivation pointing to interpersonal relationships, while boys' motivation is more to attainment. Thirdly, social tradition and cultural role concepts may directly affect the formation of the difference of attainment between men and women. Traditional social and cultural gender roles will affect women's current ideology and attainment performance and affect the development of attainment motivation of boys and girls through their parents and teachers. Social psychology suggested that the higher the social expectation, the higher the level of individual attainment motivation [31]. For a long time, society has had high expectations of women's family roles and relatively low expectations of women's professional roles, which greatly affects people's employment and career psychology. Therefore, even if women have rich knowledge and higher skills and form higher career pursuits, it is a common fact that society has a low expectation of women's employment and attainment. Whether women agree with this expectation or not will be affected, and their employment expectations will be reduced under the restriction of social facts [31].

To sum up, gender differences in attainment motivation do exist, but they are not immutable. The difference does not mean that men are better than women. 
Women's attainment may be higher than men's. There are physiological reasons for the difference, but it results from the socialization of different roles between the two sexes.

\section{CONCLUSION}

The learning stage of students at school is very important, but the problems caused by gender differences in students at this stage are also obvious. To this end, some countries have launched investigations and adopted some targeted measures. In summary, this paper shows that: In some fields in some countries, surveys have found that girls perform better than boys in most fields. Schools and governments provide different courses for students of different genders to balance student development and develop student specialties. Similarly, the stereotypes in society and the family invisibly restrict the future choices and achievements of students of different genders; By contrast, women in the education from high school, on the whole, maintain better performance and development potential than men, but women receive education The chance of being is significantly lower than that of men, and the other two sexes both show that they are restricted by gender in their career choices; In addition, gender stereotypes start from children's picture books to adult career choices, life habits, and family role-playing. They all show clear boundaries in these aspects. Although this stereotype has a certain role in stabilizing social order, it is more important. To a large extent, it shows unfair restraints and restrictions on people. These findings can help relevant workers engaged in educational research to provide some help.

\section{REFERENCES}

[1] Sekhar, P. A., \& Parameswari, J. Gender Stereotype in Education. Journal of Xi'an University of Architecture \& Technology, 12(3), 4353-4369.

[2] Demir, Y., \& Yavuz, M. (2017). Do ELT coursebooks still suffer from gender inequalities? A case study from Turkey. Journal of Language and Linguistic Studies, 13(1), 103-122.

[3] Mineshima, M. (2008). Gender representations in an EFL textbook. Bulletin of Niigata Institute of Technology, 13, 121-140.

[4] Buchmann, C., DiPrete, T. \& McDaniel, A. (2007). Gender inequalities in education. Annual Review of Sociology, 34, 319-337.

[5] Freeman, C. E. (2004). Trends in Educational Equity of Girls \& Women: 2004. NCES 2005-016. National Center for Education Statistics, 15-20.

[6] Snyder TD, Dillow SA, Hoffman CM. Digest of education statistics 2007. Washington, DC:
National Center for Education Statistics, Institute of Education Sciences, U.S. Department of Education; 2008. (NCES 2008-022)

[7] Buchmann, C. (2009). Gender inequalities in the transition to college. Teachers College Record, 111, $2320-2346$.

[8] Snyder, Thomas D., Alexandra G. Tan, and Charlene M. Hoffman. 2006. Digest of Education Statistics, 2005 (NCES 2006-030). U.S. Department of Education, National Center for Education Statistics. Washington, DC: U.S. Government Printing Office.

[9] Horn, L. \& Premo, M. (1995). Profile of Undergraduates in U.S. Postsecondary Institutions. Washington, DC: National Center for Education Statistics.

[10] Bozick, R., \& DeLuca, S. (2005). Better late than never? Delayed enrollment in the high school to college transition. Social Forces, 84, 527-550.

[11] Freeman, C. E. (2004). Trends in educational equity of girls \& women: 2004. Washington, DC: U.S. Government Printing Office.

[12] Sanders, J. (in press). Gender and technology: A research review. In C. Skelton, B. Francis, \& L. Smulyan (Eds.), Handbook of gender and education. London: Sage.

[13] Beede, D., Julian, T., Langdon, D., McKittrick, G., Khan, B., \& Doms, M. (2011). Women in STEM: A gender gap to innovation (ESA Issue Brief \#04-11).

[14] Liu Xiaohua, \& Chen Siyu. (2018). The phenomenon and analysis of gender prejudice in early reading promotion — Analysis of "mustread picture books for boys/girls". Library Theory and Practice, (12), 17-20.

[15] Brown, C. S., Alabi, B. O., Huynh, V. W., \& Masten, C. L. (2011). Ethnicity and gender in late childhood and early adolescence: group identity and awareness of bias. Developmental psychology, 47(2), 463-471.

[16] Robinson, K. H. (2014). Building respectful relationships early: educating children on gender variance and sexual diversity. a response to damien riggs. Contemporary Issues in Early Childhood, 14(1), 81-87.

[17] Buchmann, Claudia, Thomas A. DiPrete, and Anne McDaniel. (2008). Gender Inequalities in Education. Annual Review of Sociology, 34,31937.

[18] Lu, G., Liu, S. and Zhong, Y. 2009. An analysis of gender disparity in the demand of higher education 
and choice of study subject. Journal of Higher Education. 30(10), 14-29.

[19] Hongbin, \& Junsen. (2008). Human Capital Investment and Return in China. Beijing: Peking University Press.

[20] Das Gupta, Monica, Jiang Zhenghua, Li Bohua, Xie Zhenming, Woojin Chung, and Bae Hwaok. 2003. "Why is son preference so persistent in East and South Asia? A cross-country study of China, India and the Republic of Korea. Journal of Development Studies, 40(2), 153-187.

[21] Altinok N. and A. Aydemir. (2015). The Unfolding of Gender Gap in Education, Working Papers of BETA 2015-13, Bureau d'Economie Theorique et Appliquee, UDS, Strasbourg.

[22] Lei Wang. (2007). Sociological study of abnormal sex ratio at birth (Doctoral dissertation, Northeast Normal University).

[23] Bradley, K. (2000). The incorporation of women into higher education: Paradoxical outcomes?. Sociology of education, 1-18.

[24] Blake, J. (2020). Family size and achievement. Berkeley: University of California Press.

[25] Heer, D. M. (1985). Effects of sibling number on child outcome. Annual review of sociology, 11(1), 27-47.

[26] Steelman, L. C., \& Powell, B. (1985). The social and academic consequences of birth order: Real, artifactual, or both? Journal of Marriage and the Family, 24, 117-124.

[27] Clarke, E. L. (1916). American Men of Letters; Their Nature and Nurture. Stud. Hist. Econ. and Public Law: Columbia Univ., whole, 168-169.

[28] Greenhalgh, S. (1985). 'Sexual Stratification: The Other Side of "Growth with Equity" in East Asia', Population and Development Review, 11(2), 265314.

[29] Rogers, M. A., Theule, J., Ryan, B. A., Adams, G. R., \& Keating, L. (2009). Parental involvement and children's school achievement: Evidence for mediating processes. Canadian Journal of School Psychology, 24(1), 34-57.

[30] Popilskis, L. B. (2013). The link between students' achievement goals and perceptions of the classroom environment. Unpublished Doctoral Dissertation, Fordhman University, New York.

[31] Rubie-Davies, C. M., Peterson, E., Irving, E., Widdowson, D., \& Dixon, R. (2010).

Expectations of achievement: Student teacher and parent perceptions. Research in Education, 83(1), 36-53. 